U.S. Department of the Interior

U.S. Geological Survey

\title{
Volcano Hazards in the San Salvador Region, El Salvador
}

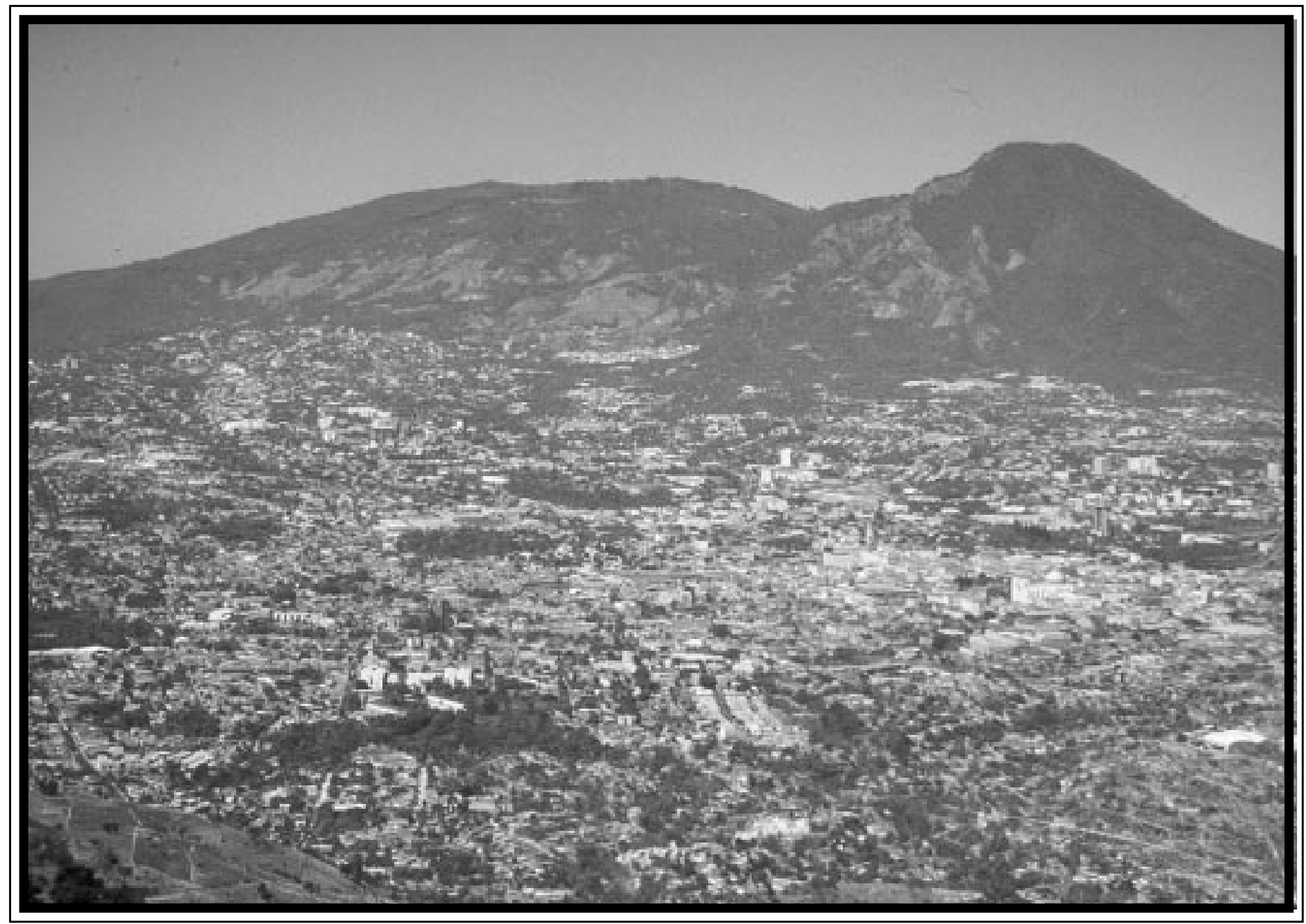

Open-File Report 01-366

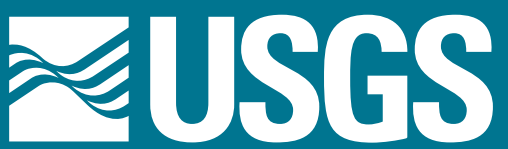




\section{Cover photograph}

San Salvador volcano viewed from the southeast. The broad edifice of El Boquerón is on the left, and steep-sided El Picacho is on the right. San Salvador city is in the foreground. (Photograph by J.J. Major, U.S. Geological Survey). 


\title{
Volcano Hazards in the San Salvador Region, El Salvador
}

\author{
By J.J. Major, S.P. Schilling, D.J. Sofield, C.D. Escobar, and C.R. Pullinger
}

U.S. GEOLOGICAL SURVEY

Open-File Report 01-366 


\section{U.S. DEPARTMENT OF THE INTERIOR \\ Gale Norton, Secretary}

U.S. GEOLOGICAL SURVEY

Charles G. Groat, Director

This report is preliminary and has not been reviewed for conformity with U.S. Geological Survey editorial standards. Any use of trade, product, or firm names is for descriptive purposes only and does not imply endorsement by the U.S. Government.

For additional information write to:

Scientist-in-Charge

U.S. Geological Survey

1300 SE Cardinal Court, Bldg. 10

Vancouver, WA 98683

(360) $993-8900$

FAX: (360) 993-8980
Copies of this report can be purchased from:

U.S. Geological Survey

Information Services

P.0. Box 25286

Denver, CO 80225

(303) 202-4210 


\section{CONTENTS}

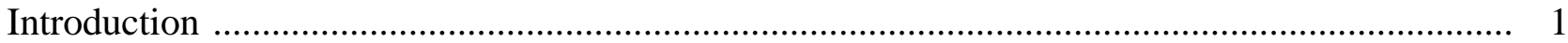

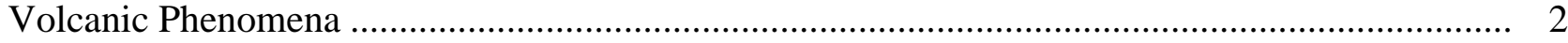

Hazardous phenomena at composite volcanoes ...................................................................... 4

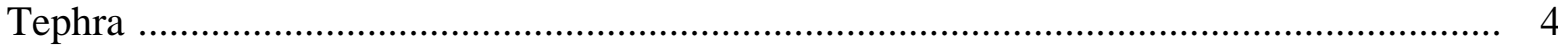

Pyroclastic flow and pyroclastic surge ..................................................................... 5

Lava flows and lava domes ..................................................................................... 5

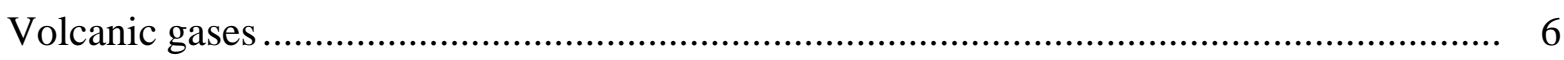

Debris avalanche, landslide, and lahar ............................................................................ 6

Hazardous phenomena at monogenetic volcanoes ............................................................. 7

Past Events at San Salvador Volcano ……...................................................................... 7

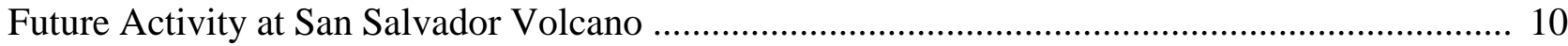

Events at Other Volcanoes Can Affect the San Salvador Region ................................................. 11

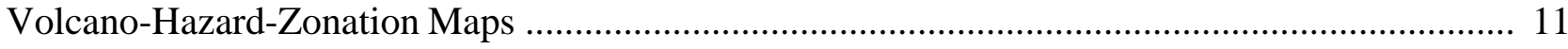

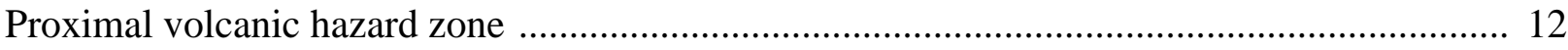

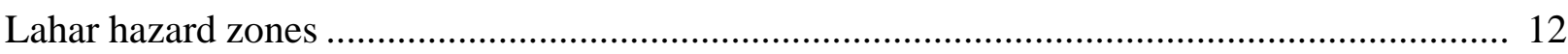

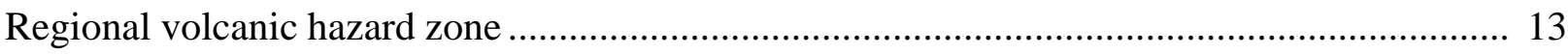

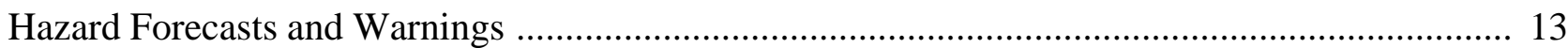

Protecting Communities and Citizens from Volcano-Related Hazards ........................................ 14

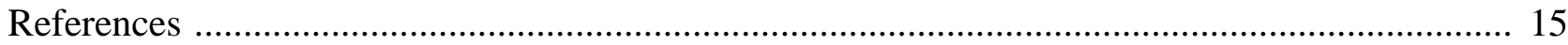

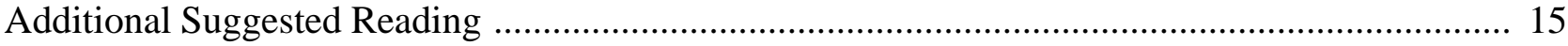

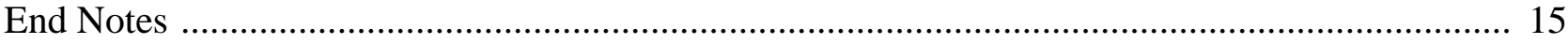

\section{PLATES [In pocket]}

1. Volcano hazards in the San Salvador region, El Salvador. Proximal-volcanic and lahar hazard zones from an event at San Salvador volcano.

2. Volcano hazards in the San Salvador region, El Salvador. Regional volcanic hazard zone that could be affected by eruptions of monogenetic volcanoes.

\section{FIGURES}

1. Location of major cities and significant Quaternary volcanoes in El Salvador ....................... 2

2. Simplified sketch showing hazardous events associated with volcanoes like San Salvador .... 3

3. Summary of eruptive history of San Salvador volcano, based largely on Sofield (1998) ........ 8 



\title{
Volcano Hazards in the San Salvador Region, El Salvador
}

\author{
By J.J. Major, S.P. Schilling, D.J. Sofield ', C.D. Escobar ${ }^{2}$, and C.R. Pullinger ${ }^{2}$
}

\section{INTRODUCTION}

San Salvador volcano is one of many volcanoes along the volcanic arc in El Salvador (figure 1). This volcano, having a volume of about 110 cubic kilometers, towers above San Salvador, the country's capital and largest city. The city has a population of approximately 2 million, and a population density of about 2100 people per square kilometer. The city of San Salvador and other communities have gradually encroached onto the lower flanks of the volcano, increasing the risk that even small events may have serious societal consequences. San Salvador volcano has not erupted for more than 80 years, but it has a long history of repeated, and sometimes violent, eruptions. The volcano is composed of remnants of multiple eruptive centers, and these remnants are commonly referred to by several names. The central part of the volcano, which contains a large circular crater, is known as El Boquerón, and it rises to an altitude of about 1890 meters. El Picacho, the prominent peak of highest elevation (1960 meters altitude) to the northeast of the crater, and El Jabali, the peak to the northwest of the crater, represent remnants of an older, larger edifice. The volcano has erupted several times during the past 70,000 years from vents central to the volcano as well as from smaller vents and fissures on its flanks [1] (numerals in brackets refer to end notes in the report). In addition, several small cinder cones and explosion craters are located within 10 kilometers of the volcano. Since about 1200 A.D., eruptions have occurred almost exclusively along, or a few kilometers beyond, the northwest flank of the volcano, and have consisted primarily of small explosions and emplacement of lava flows. However, San Salvador volcano has erupted violently and explosively in the past, even as recently as 800 years ago. When such eruptions occur again, substantial population and infrastructure will be at risk.

Volcanic eruptions are not the only events that present a risk to local communities. Another concern is a landslide and an associated debris flow (a watery flow of mud, rock, and debris--also known as a lahar) that could occur during periods of no volcanic activity. An event of this type occurred in 1998 at Casita volcano in Nicaragua when extremely heavy rainfall from Hurricane Mitch triggered a landslide that moved down slope and transformed into a rapidly moving debris flow that destroyed two villages and killed more than 2000 people. Historical landslides up to a few hundred thousand cubic meters in volume have been triggered on San Salvador volcano by torrential rainstorms and earthquakes, and some have

\footnotetext{
${ }_{2}^{1}$ GeoEngineers, Inc., Tacoma, WA, 98402, U.S.A.

${ }^{2}$ Servicio Nacionale de Estudios Terretoriales, Ave. Roosevelt y 55 Ave. Norte, Torre El Salvador (IPSFA)
} 
transformed into debris flows that have inundated populated areas down stream. Destructive rainfalland earthquake-triggered landslides and debris flows on or near San Salvador volcano in September 1982 and January 2001 demonstrate that such mass movements in El Salvador have also been lethal.

This report describes the kinds of hazardous events that occur at volcanoes in general and the kinds of hazardous geologic events that have occurred at San Salvador volcano in the past. The accompanying volcano-hazards-zonation maps show areas that are likely to be at risk when hazardous events occur again.

\section{VOLCANIC PHENOMENA}

Volcanoes pose a variety of geologic hazards-both during eruptions and in the absence of eruptive activity (figure 2). Many of the hazardous events depicted in figure 2 have occurred at San
Salvador volcano in the past and will likely occur in the future. Most of these events are caused by the eruption of molten rock, or magma, but some, like debris avalanches (landslides) and lahars, can occur without eruptive activity. The nature and scale of eruptive activity depends in part on the size and type of volcano, the composition of the magma, and on interactions between magma and water.

Two types of volcanoes are present in the San Salvador region: composite volcanoes and monogenetic cones. Composite volcanoes erupt episodically over time intervals of thousands to hundreds of thousands of years and can have a wide range of eruption styles. San Salvador volcano is a composite volcano that has been active episodically for more than 70,000 years.

Monogenetic volcanoes typically erupt for only brief intervals of time--weeks to perhaps centuries--and they generally have a narrower range in eruptive behavior. The magma of many

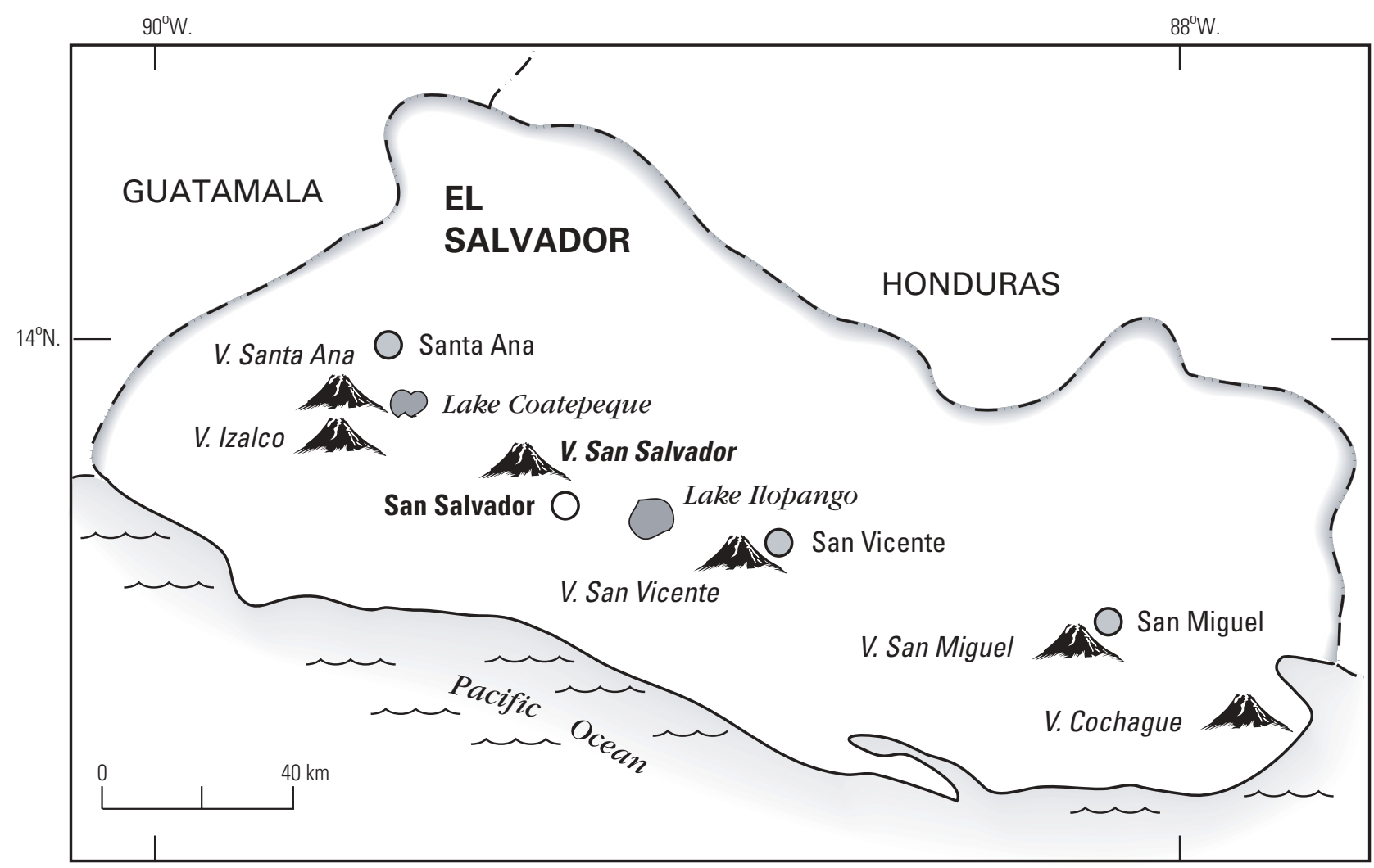

Figure 1. Location of major cities and significant Quaternary volcanoes in El Salvador. Circles indicate major cities, triangles indicate major volcanoes. Lake Coatepeque and Lake Ilopango are large silicic calderas. 


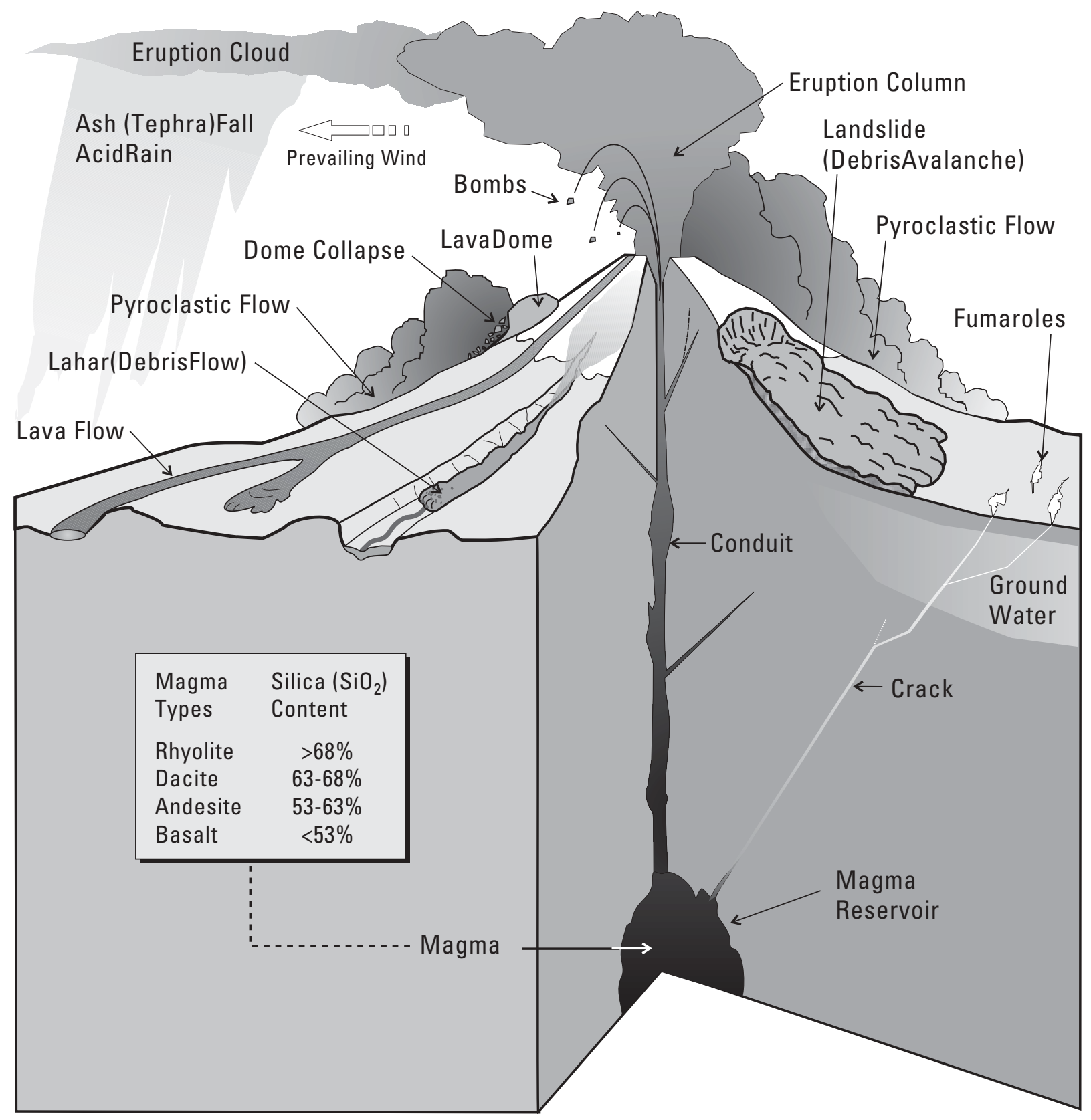

Figure 2. Simplified sketch showing hazardous events associated with volcanoes like San Salvador. Events such as lahars and landslides (debris avalanches) can occur even when the volcano is not erupting. Inset box shows classification of magma types on the basis of silica content. Illustration by Bobbie Meyers, modified from USGS Fact Sheet 002-97. 
monogenetic volcanoes is basaltic in composition, but some magmas may have higher silica contents that range from andesite to dacite (see inset figure 2). The more silica in the magma, the more explosive an eruption. In the San Salvador region, eruptions of monogenetic volcanoes have produced explosion craters, cinder cones, and lava flows.

The rocks from most of these monogenetic centers have andesitic compositions (silica contents ranging from about $54 \%$ to $61 \%$ ), but a few have basaltic compositions ( $<53 \%$ silica content). Prominent cinder cones in the area include Cerro El Playón, Montána Quezaltepeque, Plan del Hoyo, Cerro Las Viboras and Laguna Caldera (Plates 1 and 2). Prominent explosion craters include Laguna de Chanmico, Resumidero crater, crater Las Granadillas, and other unnamed craters mainly on the northwest flank of the volcano (Plates 1 and 2). Lava flows erupted from monogenetic centers or from fissures on the volcano's flanks are found mainly to the north and extend a few kilometers northwest of Quezaltepeque.

\section{Hazardous phenomena at composite volcanoes}

\section{Tephra}

As magma nears the surface of a volcano, gases dissolved in the magma are released. If the gas is released rapidly then the magma can be broken explosively into small fragments and be dispersed into the atmosphere. Fragments from such eruptions, which range in size from microscopic ash to meter-sized blocks, are collectively called tephra. Tephras form deposits that blanket broad areas downwind from a volcano. A deposit's thickness and particle size generally decrease away from the vent, but a deposit can cover large areas tens to hundreds of kilometers from the source. The largest tephra fragments, called ballistic projectiles, fall to the ground within a few kilometers of the vent.

Tephra falls seldom threaten life directly, except within a few kilometers of a vent. Large ballistic fragments are capable of causing death or injury by impact. Large projectiles may also still be hot when they land and can start fires if they fall onto combustible material. Most injuries and fatalities from tephra falls occur when the tephra accumulations are thick, or are saturated by rainfall, and thus are heavy enough to collapse building roofs. Fine tephra suspended in the air can irritate eyes and respiratory systems and exacerbate pulmonary problems, especially in the elderly and infants.

Indirect effects of tephra falls can be perhaps more disruptive than the direct effects of tephra falls. Even thin accumulations of tephra fall can significantly disrupt social and economic activities over broad regions. Tephra plumes can create tens of minutes or more of darkness, even on sunny days, and tephra falls can reduce visibility and navigability on highways. Tephra ingested by vehicle engines can clog filters and increase wear. Deposits of tephra can short-circuit or break electric transformers and power lines, especially if the tephra is wet, sticky, and heavy. Tephra can contaminate surface-water drinking supplies, plug storm- and sanitary-sewer systems, and clog irrigation canals. Even thin tephra accumulations may ruin sensitive crops. A serious potential danger of tephra stems from the threat of even small, dilute tephra clouds to jet aircraft that fly into them. Ingestion of even small amounts of tephra into jet engines can cause them to malfunction and lose power.

Lessons learned from the 1980 eruption of Mount St. Helens in the United States can help governments, businesses, and citizens to prepare for future tephra falls. Communities downwind of Mount St. Helens experienced significant disruptions in transportation, business activity, and services from fallout of as little as 5 millimeters of tephra. The greater the amount of tephra fall, the longer it took for a community to recover. As perceived by residents, tephra falls of less than 5 millimeters were a major inconvenience, whereas falls of more than $150 \mathrm{~mm}$ constituted a disaster. Nonetheless, all of the downwind communities affected by Mount St. Helens resumed normal activity within about two weeks of the event.

Eruptions of San Salvador volcano and associated cinder cones have deposited several tephra layers over the past 70,000 years [1]. Although many of the layers are relatively thin (less than several centimeters thick) beyond the volcano, an eruption that occurred about 30,000 to 40,000 years ago deposited a tephra layer that is as 
much as 1 meter thick within 10 kilometers of the volcano. This tephra layer is composed mainly of pumice, a light frothy fragment of exploded magma, which indicates that gas-rich magma intruded the volcano and erupted violently. The compositions, textures, and distributions of other tephra layers, especially those erupted from cones on the flanks of the volcano, indicate that some explosive eruptions were phreatomagmatic and involved interactions of magma and water.

\section{Pyroclastic flow and pyroclastic surge}

Sometimes the mixture of hot gases and volcanic rock particles produced by an explosive eruption is denser than air, and instead of rising above the vent to produce tephra, this dense mixture behaves like a fluid, stays close to the ground, and flows downslope. If the mixture is made up mostly of rock particles, then it has a high density and its path will be confined to topographically low areas, much as topography will control the flow of water. This type of dense flow is called a pyroclastic flow. However, if the mixture is made up mostly of gas with a small proportion of rock fragments, then it will have a lower density and its path will be less controlled by topography. This type of gas-rich mixture is called a pyroclastic surge. Pyroclastic flows and surges also produce ash clouds that can rise thousands of meters into the air, drift downwind, and transport tephra for tens of kilometers or more from a volcano.

Pyroclastic flows and surges often occur together, and both are exceedingly hazardous. They move at such rapid speeds, 50 to 150 kilometers per hour, that escape from their paths is difficult or impossible. Temperatures in pyroclastic flows and surges commonly are several hundred degrees Celsius or more. Owing to their high density, high velocity, and high temperature, pyroclastic flows can destroy all structures and kill all living things in their paths by impact, burial, or incineration. Although pyroclastic surges are more dilute and less dense than pyroclastic flows, surges can affect larger areas and still be very destructive and lethal. People and animals caught in pyroclastic surges can be killed directly by trauma, severe burns, or suffocation.
There have been at least two eruptive episodes at San Salvador volcano that have produced pyroclastic flows and surges. One episode is related to an eruption that produced the thick pumice tephra-fall deposit about 30,000 to 40,000 years ago. A younger eruptive episode in 1200 A.D. also produced pyroclastic flows and surges.

\section{Lava flows and lava domes}

Lava is liquid magma that reaches Earth's surface nonexplosively. Depending on its viscosity and rate of discharge, lava will form a bulbous lava dome over a vent or a lava flow that can travel several kilometers or more down slope from a vent. Lava flows commonly move down slope as streams of molten rock a few to tens of meters thick. The rate at which lavas flow depends chiefly upon their chemical composition. Basaltic lavas of the kind observed in Hawaii can move rapidly, at tens of meters per minute, whereas andesitic lavas of the kind commonly erupted by the volcanoes in El Salvador are more sluggish and move at most at a few tens of meters per hour. Although lava flows can be extremely destructive, they typically are not life threatening. People and animals can usually walk out of the path of an advancing flow. However, fronts on sluggish lava flows moving across steep slopes can sometimes collapse and generate blocks of hot debris that cascade downslope, break apart, and form hazardous, fast-moving pyroclastic flows or surges.

Lava domes can pose a greater hazard than lava flows. Lava domes form from lava that is more viscous than that in lava flows, and as a result they can grow on steep slopes or construct steepsided landforms. As lava domes grow, they can become unstable and collapse repeatedly, also generating blocks of hot debris that cascade downslope, break apart, and form hazardous, fastmoving pyroclastic flows or surges.

Lava flows extend down all flanks of San Salvador volcano, but many of the flows are concentrated on the north and northwest flanks of the volcano. Although some individual lava flows are difficult to follow completely, fields of lava flows extend from about 5 to more than 10 kilometers from the summit crater. No lava domes have been recognized at the volcano. 


\section{Volcanic gases}

All magmas contain gases that are released both during and between eruptions. Volcanic gases consist mainly of steam but also include carbon dioxide and compounds of sulfur and chlorine, as well as minor amounts of several other gases.

Generally, volcanic gases are diluted rapidly downwind from the vent, but within a few kilometers of a vent they can endanger life and health if concentrations are high and exposure is prolonged. Eyes and lungs of people and animals can be injured by acids, ammonia, and other compounds. People and animals can suffocate in denser-than-air gases like carbon dioxide, which pond and accumulate in closed depressions.

The greatest hazards arising directly from gases emitted by San Salvador volcano are likely to be confined to the summit crater, and thus of concern to those who work or recreate within the crater. Outside the summit crater, direct hazards from volcanic gases are likely to be minor.

A widerspread, but indirect, hazard arising from volcanic gases emitted by San Salvador volcano involves formation of acid rain. Compounds of sulfur are one of the main gases emitted by volcanoes, and excessive acidification of rainfall can occur when sulfur compounds combine with water vapor and droplets and form sulfuric acid that is deposited during storms. If such acid is sufficiently concentrated it can damage crops, reduce land productivity, and pollute surface water. In El Salvador, acid rain resulting from emission of volcanic gases has damaged coffee crops locally, particularly around Santa Ana volcano [2].

\section{Debris avalanche, landslide, and lahar}

The slopes of a volcano can become unstable and fail catastrophically, generating a rapidly moving landslide called a debris avalanche. Slope instability at volcanoes can be caused by many factors. Magma rising upward through a volcano can push aside older volcanic rock and deform and steepen the flanks of a volcano, or warm acidic ground water can circulate through cracks and porous zones inside a volcano, alter strong rock to weak slippery clay, and gradually weaken the volcano so that it is susceptible to debris avalanches. A volcano's slopes can also fail without direct involvement of magma. Unexpected earthquakes, torrential rains, or steam explosions can trigger slope failures, but these failures are commonly smaller in volume than those triggered by magmatic intrusion. A debris avalanche can attain speeds in excess of 150 kilometers per hour; generally, the larger the avalanche, the faster and farther it can travel. Small-volume debris avalanches typically travel only a few kilometers from their source, but large-volume debris avalanches can travel tens of kilometers from a volcano. Debris avalanches destroy everything in their paths and can leave deposits of 10 meters to more than 100 meters thick on valley floors.

Deposits of debris avalanches have been recognized at numerous volcanoes around the world, including volcanoes in El Salvador. However, no deposits of large debris avalanches have yet been recognized at San Salvador volcano, suggesting that large parts of the volcano have not collapsed catastrophically. Nevertheless, San Salvador volcano is a large volcano, and the possibility of a future flank collapse cannot be dismissed.

Lahars, also called mudflows and debris flows, are flowing masses of mud, rock, and water that look much like flowing concrete. They are produced when water mobilizes large volumes of loose mud, rock, and volcanic debris. Commonly, landslides and debris avalanches transform into lahars as they move down valley. Lahars, like floods, inundate floodplains and submerge structures in low-lying areas. They can travel many tens of kilometers at speeds of tens of kilometers per hour. Lahars can destroy or damage everything in their paths through burial or impact. They follow river valleys and leave deposits of muddy sand and gravel that can range from a few to tens of meters thick. They are particularly hazardous because they travel farther from a volcano than any other hazardous phenomenon except tephra, and they affect stream valleys where human settlement is usually greatest. In some instances, landslides and lahars can clog a channel or block a tributary channel and impound a lake behind the blockage. Commonly, the impounded water will spill over the blockage, quickly cut a channel, catastrophically drain the lake, and generate a flood that moves 
down valley endangering people and property. Breaching of the blockage may occur within hours to months after impoundment.

Like floods, lahars range greatly in size. The smallest lahars recur most frequently (perhaps every few years), whereas the largest recur on the order of centuries to millennia. The size of lahars is controlled by both the amount of water and the amount of loose sediment or volcanic debris available. Large debris avalanches or eruptions can dump tens to hundreds of millions of cubic meters of sediment into channels and produce large lahars. Small debris avalanches or eruptions produce smaller lahars. Lahars have occurred on San Salvador volcano, and historical landslides and lahars of more than 100,000 cubic meters in volume have failed from the volcano's steep upper slopes and traveled more than 4 kilometers from their sources [1].

Landslides and lahars can cause problems long after the event that formed them ends. Once landslides and lahars fill stream channels with sediment, the streams begin to erode new paths, and the new stream channels can be highly unstable and shift rapidly as sediment is eroded and moved farther down valley. Rapid stream shifting can cause rapid and dramatic bank erosion.

Furthermore, because stream channels are clogged with sediment, they have less ability to convey water. As a result, relatively small floods, which may have previously passed unnoticed, can pose potentially significant threats to people living in low-lying areas. In general, people living in lowlying areas along river valleys are most susceptible to these secondary affects from landslides and lahars, but areas on higher ground adjacent to river channels apparently safe from flooding may be threatened by bank erosion. Examples from many volcanoes around the world show that the effects of sediment deposition by landslides and lahars in stream channels can persist for years to decades [3].

\section{Hazardous phenomena at monogenetic volcanoes}

Monogenetic volcanoes in the San Salvador area have dominantly andesitic composition. Although their compositions are similar to those of many eruptive products from San Salvador volcano, the effects of their eruptions generally do not extend far from the source. Future eruptions of monogenetic craters and cinder cones may involve modest explosions and emplacement of lava flows. Perhaps the most dangerous events associated with monogenetic volcanoes occur when rising magma interacts with surface water or shallow ground water and produces steam explosions and pyroclastic flows or pyroclastic surges, which can travel rapidly outward for several kilometers from the vent. Deposits and explosion craters produced by interactions of magma and water are found on the northwest side of San Salvador volcano.

\section{PAST EVENTS AT SAN SALVADOR VOLCANO}

San Salvador volcano has erupted intermittently for more than 70,000 years, and historical observations of eruptions date back nearly 500 years [1]. However, only three eruptions have occurred since the early 1500's, and those eruptions consisted of a series of small explosions of low viscosity basaltic magma and emplacement of basaltic lava flows on the flanks of the volcano. Most of the information about San Salvador's past behavior comes from studies of deposits produced by prehistoric events. Many details of past eruptions as well as the precise age of the volcano are unknown, but it is clear that the volcano has exhibited a wide range of eruptive behaviors--from highly explosive events to relatively quiet lava flows (figure 3 ).

The bulk of the volcano was constructed more than 70,000 years ago. The oldest rocks exposed at San Salvador underlie deposits from a 72,000-yearold eruption of Coatepeque, a caldera that is located about 50 kilometers west of San Salvador [4]. These old rocks of San Salvador volcano consist of blocky basaltic to andesitic lavas and tephras, and they are exposed at the bases of El Picacho and El Jabali and in scattered outcrops around the volcano. El Picacho and El Jabali consist entirely of layered volcanic rocks that dip away from the center of the volcano, suggesting that these two peaks are remnants of an ancestral cone, which is called the San Salvador edifice. Presently, El Picacho and El Jabali mark the 


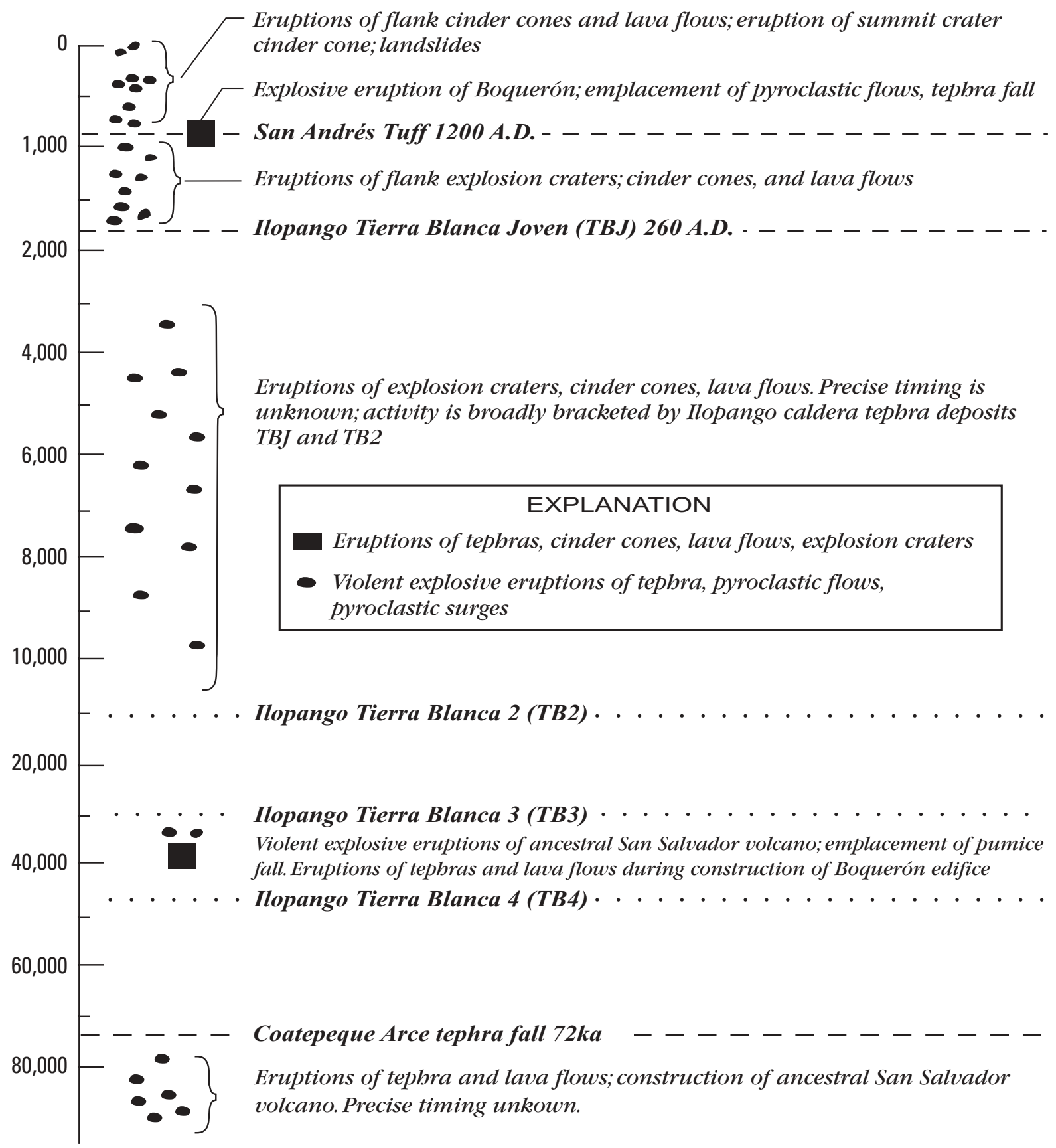

Figure 3. Summary of eruptive history of San Salvador volcano, based largely on Sofield (1998). Timescale is approximately calendar years. Regional fall deposits having known dates are shown as dashed lines; regional fall deposits having approximate dates are shown as dotted lines. 
location of an older volcanic edifice that has been deeply incised. Beyond the volcano, outcrops expose sections of a series of andesitic and basaltic tephra-fall deposits. Some of these fall deposits are only a few centimeters thick and are separated by erosional surfaces, suggesting that they are deposits from many small explosive eruptions that occurred during a long interval of time.

A distinctive gray, dacitic pumice-fall deposit, known as the G1 unit, marks a significant episode of explosive activity at San Salvador volcano. The G1 deposit is widespread and locally is more than 1 meter thick within 10 kilometers of the volcano's crater. Near El Picacho, this distinctive fall deposit is interlayered with pyroclastic-flow and surge deposits, and multiple flow and surge deposits extend about 6 kilometers from the summit. Rock fragments within these flow and surge deposits consist of the older San Salvador lavas. The nature and volume (about 2 to 8 cubic kilometers) of the flow and surge deposits indicate a large explosive eruption that may have largely destroyed the older San Salvador edifice and formed the crater now defined by the peaks of El Picacho and El Jabali. Although the exact timing of this event is unknown, stratigraphic relations with tephra-fall deposits from eruptions of Ilopango caldera, which is located on the eastern outskirts of San Salvador city, help constrain the time of this eruption. The G1 unit lies between Ilopango caldera tephra-fall deposits Tierra Blanca 3 (TB3) and Tierra Blanca 4 (TB4). On the basis of paleosols, buried soil horizons, formed on these tephra deposits, TB4 has been estimated to be about 40,000 to 50,000 years old.

Eruptions subsequent to the G1 fall deposit produced tephras and lava flows that now largely fill the crater formed during the G1 eruption and form a cone called El Boquerón. El Boquerón is composed of multiple blocky lava flows interlayered with tephra-fall deposits, all of which are chemically distinct from the lava flows of the ancestral San Salvador edifice. Lava flows from El Boquerón spilled over the north, east, and south rims of the San Salvador edifice. In addition to eruptions from the central crater, several smaller explosion craters, cinder cones, and lava flows erupted on the volcano's flanks.
El Boquerón volcano exploded violently about 800 years ago in an eruption that was perhaps similar to, but smaller than, the eruption that produced the G1 fall deposit. Pyroclastic-flow and tephra-fall deposits, known as the San Andrés tuff, are found at the rim of El Boquerón, and these deposits have been correlated with similar deposits, known as the Talpetate tephra fall, on the western flank of San Salvador volcano. The Talpetate tephra has been dated archeologically at 1200 A.D. Together, the Talpetate fall and San Andrés tuff deposits have a volume of about 0.5 cubic kilometers, indicating that this explosive eruption was roughly one tenth as large as the eruption that produced the G1 fall deposit. Sedimentary structures in the Talpetate fall deposit suggest that it was produced by an eruption in which the magma interacted with water.

Some of the youngest volcanic features and deposits at San Salvador volcano are along the northern and northwestern flanks of the volcano. These features and deposits consist of explosion craters, cinder cones, and lava flows that are generally concentrated along two prominent fault zones. Several explosion craters formed between 260 A.D and 1200 A.D. They are older than the San Andrés tuff deposits, but overlie the distinctive Tierra Blanca Joven (TBJ) tephra deposit, the youngest regional deposit associated with eruptions of Ilopango caldera [4]. Many of these explosion craters show evidence that they are products of eruptions in which the magma interacted with water.

Many monogenetic cinder cones and associated lava flows are on the northern and northwestern flanks of San Salvador volcano and beyond (Plates 1 and 2). Many of these cinder cones and lava flows are younger than the San Andrés tuff deposit, and thus are less than 800 years old. Three prominent lava flows formed on and beyond the northwestern flank of San Salvador volcano within the past 500 years. In addition to these volcanic events, landslide deposits younger than the Talpetate tephra are present on the northern and northwestern flanks.

The most recent volcanic activity at San Salvador began in June, 1917, when, following an earthquake, steam billowed from El Boquerón 
crater and several fissures opened along the northwestern flank of the volcano. Within a month of this activity, a lake in the crater of El Boquerón had boiled off, and small explosions formed a cinder cone called Boqueróncito. The eruption lasted several months, constructed Boqueróncito and extruded a lava flow on the northwestern flank of the volcano. After the 1917 eruption, fumarolic activity continued until the late 1970's.

Although no eruptive activity has occurred at San Salvador volcano for more than 80 years, lethal volcano-related events have occurred. In 1982, heavy rainfall triggered numerous landslides in $\mathrm{El}$ Salvador, and at San Salvador volcano a rainfalltriggered landslide from the flank of El Picacho swept along a channel and into the northwest part of the city. The landslide, having a volume of between 200,000 to 300,000 cubic meters, rapidly transformed into a lahar that traveled more than 4 kilometers from its source. Near the base of the volcano the lahar destroyed or buried several homes and killed between 300 and 500 people.

More than 30 volcanic events have occurred at San Salvador volcano in the past 40,000 years (figure 3). Hence, the average apparent frequency of eruptions is roughly 1 per 1300 years. The volcano has undoubtedly erupted more frequently, because some eruptions do not leave conspicuous deposits in the geologic record. If we separate eruptive events into discrete, datable time periods, then we establish the following apparent frequencies of eruptions: between 40,000 years ago and 260 A.D. about 13 identifiable events indicate an eruption frequency of about 1 event per 3000 years. Between 260 A.D. and 1200 A.D. about 9 identifiable eruptive events indicate an eruption frequency of about 1 event per 100 years. Between 1200 A.D. and 1917 about 9 identifiable eruptive events indicate an eruption frequency of about 1 event per 80 years. These eruption frequencies are only statistically averaged values. Many of these eruptive events are likely associated with a single eruptive episode, such as eruptions of cinder cones and lava flows, rather than distinct events widely separated in time. The apparent eruption frequencies should not be interpreted to mean that the time between eruptions is necessarily decreasing. The apparent decrease with time is related primarily to better preservation of younger deposits. Neverthe- less, even accounting for the imperfections of the geologic record, evidence clearly indicates that San Salvador volcano erupts sufficiently frequently, with an annual probability of perhaps 1 in 1000 , that potential hazards from future eruptions need to be taken seriously, as densely populated areas will be at risk.

\section{FUTURE ACTIVITY AT SAN SALVADOR VOLCANO}

On the basis of eruptive activity during the past 2000 years, future eruptive activity at San Salvador volcano may involve violent eruptions from the summit crater, and likely will involve relatively small explosions and tephra fall from the summit crater and monogenetic centers, and emplacement of lava flows on or beyond the flanks of the volcano. The volcano has erupted violently at least twice from the central summit crater, once as recently as 800 years ago, and could do so again in the future. Explosive eruptions are more dangerous than those that generate lava flows or cinder cones. Such explosive eruptions can produce pyroclastic flows and pyroclastic surges that simultaneously affect multiple sectors of the volcano, as well as produce thick tephra falls and lahars that could affect areas more than 10 kilometers from the volcano. If magma rising into the volcano or a nearby monogenetic center interacts with ground water or shallow surface water, it could produce energetic steam explosions and destructive pyroclastic surges. Landslides and lahars, triggered by any of several mechanisms, can occur on any flank of the volcano.

The primary effects of future eruptions or landslides will likely be confined to within about 10 kilometers of the summit of the volcano. However, large lahars could travel more than 10 kilometers away from the summit, monogenetic centers could erupt beyond a 10-kilometer radius, and heavy tephra fall could be carried more than 10 kilometers downwind.

Upper-level wind patterns in Guatemala between 3000 and 15,000 meters altitude are strongly seasonal [5]. Similar wind patterns are likely in El Salvador. From January to March, westerly winds dominate. April and May are 
transitional months in which westerly winds give way to more northerly and easterly winds. June through October are characterized by easterly winds, and November and December are transitional months during which westerly winds gradually become dominant. The strong seasonality of these winds will influence areas affected by tephra falls. Erupted tephras will likely fall eastward of the volcano from January through March, potentially cover broad regions to the east, south, and west in April and May, affect areas west of the volcano from June through October, and possibly areas west, north, and east of the volcano in November and December. Surface winds may also affect tephra distributions, and their patterns are diurnal as well as seasonal [5]. Therefore, all sectors around San Salvador volcano can be affected by tephra fall, but some areas are more likely to be affected than others depending upon the season in which an eruption occurs.

The primary effects of eruptions and landslides are serious, but secondary effects can be equally as severe, can affect areas beyond the zone of primary impact, and can linger for several years. Such secondary effects, which are associated chiefly with sediment deposited in river channels by landslides and lahars, involve reworking and redistribution of sediment, bank erosion, loss of channel capacity, and enhanced hazards of floods in low-lying areas. Secondary effects that occur in the aftermath of an eruption of San Salvador volcano or a large landslide can affect areas many tens of kilometers down stream from the volcano.

\section{EVENTS AT OTHER VOLCANOES CAN AFFECT THE SAN SALVADOR REGION}

San Salvador volcano and nearby vents are not the only sources of volcanic hazards in the region. The most devastating volcanic events that have affected the San Salvador region are related to large explosive eruptions from Ilopango caldera, which is located on the eastern outskirts of San Salvador city (figure 1). Four explosive eruptions from this caldera within approximately the past 40,000 to 50,000 years left tephra-fall and pyroclastic-flow deposits that are as much as several meters thick in the San Salvador region. Deposits of the youngest explosive eruption from Ilopango, the regional
Tierra Blanca Joven (TBJ) unit, are dated at 260 A.D. [4], and these deposits extend from several kilometers east of San Vicente volcano (figure 1) to several kilometers west and northwest of San Salvador volcano. Such large catastrophic eruptions of Ilopango occurred about once every 10,000 to 15,000 years during the past 40,000 to 50,000 years, so the annual probability of another eruption of this magnitude at Ilopango is very low. Depending upon the season and prevailing wind directions, tephra from eruptions of other volcanoes, such as Santa Ana, San Vicente, or San Miguel (figure 1), for example, could affect the San Salvador region.

\section{VOLCANO-HAZARD-ZONATION MAPS}

The accompanying volcano-hazard-zonation maps (plates 1 and 2) show areas that could be affected by future hazardous geologic events at or near San Salvador volcano. Individual events typically affect only part of a hazard zone. The location and size of an affected area will depend on the location of an erupting vent or landslide, the volume of material involved, and the character of an eruption, especially its explosivity.

Potentially hazardous areas around San Salvador volcano are divided into proximalvolcanic, lahar, and regional-volcanic hazard zones depending on distance from the volcano and the type of hazard. The lahar hazard zones are subdivided further on the basis of the relative degree of hazard from lahars of various volumes. Hazardzone boundaries are drawn on the basis of (1) the magnitude of past events at the volcano, as inferred from deposits; (2) mathematical models that use calibrations from other volcanoes to predict the probable extent of lahars; and (3) our experience and judgement derived from observations and understanding of events at similar volcanoes.

Although we show sharp boundaries for hazard zones, the limit of the hazard does not end abruptly at these boundaries. Rather, the hazard decreases gradually as distance from the volcano increases, and for lahars decreases rapidly with increasing elevation above channel floors. Areas immediately beyond outer hazard zones should not be regarded as hazard-free, because the limits of the hazard can only be located approximately, 
especially in areas of low relief. Many uncertainties about the source, size, and mobility of future events preclude locating the boundaries of zerohazard zones precisely. Furthermore, we show only those hazards associated with events that originate at San Salvador and distal monogenetic volcanoes. Events not directly associated with activity at San Salvador volcano or surrounding monogenetic volcanoes may increase the hazards within apparently low-hazard zones shown on plates 1 and 2. A good example of this is the lethal January 2001 landslide from Balsamo Ridge, located south of San Salvador volcano, that devastated Las Colinas neighborhood near Nueva San Salvador. Plate 1 shows this area as having a relatively low degree of hazard from landslides and lahars that originate on San Salvador volcano. Las Colinas and other communities at the base of the steep ridge to the south of the volcano clearly are located in a geologically hazardous area, but hazards from regional landslides are not defined in our analysis of volcano-related events.

Users of the hazard maps in this report should be aware that the maps do not show all hazardous areas subject to landslides and lahars from San Salvador volcano. The volcano is extensively incised, and landslides could occur in any drainage. For this report, we defined zones of inundation from lahars of various volumes for prominent channels directed toward populous areas. Other channels for which we have not modeled lahar inundation should not be considered as areas devoid of lahar hazard. Landslides and lahars from other unmapped channels could just as well threaten life and property.

\section{Proximal volcanic hazard zone}

The proximal volcanic hazard zone includes areas immediately surrounding San Salvador volcano, and extends about 5 to 7 kilometers from the summit depending upon local topography [6]. This zone delineates areas subject to devastating volcanic phenomena including pyroclastic flows and surges, debris avalanches, lava flows, and ballistics. Owing to the high speed and destructiveness of many of these phenomena, escape or survival is unlikely in the proximal hazard zone. Therefore, evacuating this hazard zone during periods of volcano unrest is realistically the only way to protect lives. Debris avalanches and lahars will originate in the proximal area, and deposits from small slides and flows may be restricted to this zone. Large debris avalanches and lahars, however, will travel away from the volcano and flow onto adjacent lowlands. The extent of inundation from lahars of various volumes is the basis for defining lahar hazard zones.

\section{Lahar hazard zones}

Lahar hazard zones lie along the primary channels that drain San Salvador volcano. Depending on the distance from the volcano, these areas will be affected a few minutes to about one hour after a the onset of a lahar. Beyond 10 kilometers from the volcano's summit escape may be possible if people are given sufficient warning. Within 10 kilometers of the volcano lahars may happen too quickly to provide effective warning.

We used a mathematical technique calibrated with data from other volcanoes [7] to estimate potential areas of inundation from lahars of various volumes. For each channel analyzed, we define four to five nested hazard zones that depict anticipated inundation by hypothetical "design" lahars having different volumes. The largest design lahar, 2 million cubic meters, reflects our estimate of the largest probable lahar generated by a debris avalanche that might descend suddenly from San Salvador volcano [7]. However, a debris avalanche of sufficient volume to generate a lahar of this size requires failure of a large part of the volcano's upper flank, and such an event would likely be restricted to the eastern flank of the volcano [7]. We therefore use 1 million cubic meters as our largest design lahar from other source areas. Debris avalanches of 1 million cubic meters or more require catastrophic failures of relatively large pieces of the volcano, but avalanches of this size might occur on any flank of the volcano. Avalanches might occur in conjunction with volcanic activity, such as intrusion of magma into the edifice, that would be detected by monitoring. However, the possibility that large flank failures could be triggered by mechanisms other than magma intrusion, such as strong earthquakes or 
torrential rains, cannot be dismissed. In general, landslides and lahars triggered by mechanisms other than volcanic activity are most likely to be smaller than 1 million cubic meters in volume.

The intermediate $(300,000$ to 500,000 cubic meters) and smallest (100,000 cubic meters) design lahars are more typical lahar volumes for a small to moderate eruption or for a landslide that occurs without warning. Lahars of these sizes have occurred historically at San Salvador and other volcanoes in El Salvador, and lahars of these sizes and smaller are the most likely sizes to occur again.

Large lahars are less likely to occur than small lahars. Thus, the nested lahar-hazard zones show that the likelihood of lahar inundation decreases as distance from the volcano and elevation above the valley floors increases. To our knowledge, no lahar as voluminous as 1 million cubic meters has ever occurred at San Salvador volcano. The annual probability of a lahar of this size is difficult to estimate, but is probably less than 1 in 40,000 [8]. Smaller landslides and lahars triggered by earthquakes or torrential rains are much more likely to occur but would probably inundate only parts of the design hazard zones adjacent to stream channels. Lahars of about 300,000 cubic meters or less may have an annual probability of about 1 in 100 to perhaps as great as 1 in 10 [8].

In general, lahar hazard zones are within about 10 kilometers of the summit crater. Even the largest volume "design" lahars of 2 million cubic meters extend no more than about 15 kilometers from the summit crater. Local topography plays a large role in controlling lahar runout. Although landslides and lahars originate in and flow along steeply incised drainages on the flanks of the volcano, these channels abruptly shallow and the topography abruptly flattens near the base of the edifice. As a result, lahars rapidly spill out of channels, spread, and stop. The most distant hazard zones are associated with the deepest incised channels in which lahars will remain confined, such as in the southwestern and northeastern sectors of the edifice. Despite their relatively short runout distances, even the smallest lahars can be devastating. The city of San Salvador and surrounding communities have encroached onto the lower flanks of the volcano, and the lahar hazard zones extend well into areas that are now densely settled.

\section{Regional volcanic hazard zone}

Eruptions from monogenetic cones located beyond the flanks of San Salvador volcano have affected areas more than 10 kilometers from the summit of the volcano. Eruptions from these monogenetic vents have produced lava flows, pyroclastic surges, ballistics projectiles, and tephra falls. Much of this activity has occurred to the north and northwest of San Salvador volcano. We define a regional volcanic hazard zone (plate 2) by determining the distribution of monogenetic vents in the area and assuming that future monogenetic vents or fissures will erupt only within this area. Lava flows, pyroclastic flows and surges, and ballistic projectiles produced by eruptions from these monogenetic centers are assumed to travel a maximum of 5 kilometers from their source vent. Therefore, we establish a hazard zone boundary either 5 kilometers downslope from where vents may open, or where significant topographic features would likely stop or divert lava flows. The regional hazard zone encompasses land that is largely populated. An eruption from a monogenetic vent within this zone will cause significant societal disruption, because lava flows, pyroclastic flows, and pyroclastic surges destroy everything in their paths.

At least 8 lava flows have occurred in the past 1700 years, suggesting that the annual probability of a lava flow occurring in the local area north or northwest of the volcano is about 1 in 200 .

However, because only a relatively small area of the regional hazard zone will be affected during any given eruptive episode, and because large areas within the hazard zone never have been covered by lava flows, the annual probability for any specific point in the zone being inundated by renewed volcanism is less than 1 in 200 .

\section{HAZARD FORECASTS AND WARNINGS}

Scientists normally can recognize and monitor several indicators of impending volcanic eruptions. Magma rising into a volcano prior to an eruption 
causes changes that can usually be detected by various geophysical instruments and visual observations. Swarms of small earthquakes are generated as rock breaks to make room for rising magma or as heating of fluids increases underground pressures. Heat from the magma can increase the temperature of ground water and raise temperatures of hot springs and steaming from fumaroles; it can also generate small steam explosions. The composition and volume of gases emitted by fumaroles can change as magma nears the surface, and injection of magma into a volcano can cause swelling or other types of surface deformation.

El Salvador has a national seismic network, so a significant swarm of earthquakes at San Salvador volcano would be noticed quickly. At other volcanoes similar to San Salvador, notable increases in seismicity have occurred days to months before eruptions. An increase in seismicity near the volcano should prompt deployment of additional seismometers to better locate earthquakes, and stimulate other monitoring efforts that examine signs of volcanic unrest.

Periods of unrest at volcanoes produce times of great uncertainty. During the past few decades substantial advances have been made in volcano monitoring and eruption forecasting, but still scientists can often make only very general statements about the probability, type, and scale of an impending eruption. Precursory activity can go through accelerating and decelerating phases, and sometimes will die out without an eruption. Government officials and the public must realize the limitations in forecasting eruptions and must be prepared to cope with such uncertainty.

Despite advances in volcano monitoring and eruption forecasting, it is still difficult, if not impossible, to predict the precise occurrence of landslides triggered by earthquakes or torrential rains. Therefore, government officials and the public need to identify the locations of lahar hazard zones and realize that potentially lethal events in these hazard zones can occur with little or no warning.

\section{PROTECTING COMMUNITIES AND CITIZENS FROM VOLCANO-RELATED HAZARDS}

Communities, businesses, and citizens must plan ahead to mitigate the effects of future volcanic eruptions, landslides, and lahars from San Salvador volcano. Long-term mitigation efforts must include using information about volcano hazards when making decisions about land use and siting of critical facilities. Future development should avoid areas judged to have an unacceptably high risk or be planned and designed to reduce the level of risk.

When volcanoes erupt or threaten to erupt, a rapid, well-coordinated emergency response is needed. Such a response will be most effective if citizens and public officials have a basic understanding of volcano hazards and have planned the actions needed to protect communities.

Because a volcanic eruption can occur within days to months after the first precursory activity and because some hazardous events, such as landslides and lahars, can occur without warning, suitable emergency plans should be made in advance. Although it has been more than 80 years since San Salvador volcano erupted and it is unknown when it will erupt again, public officials need to consider issues such as public education, land-use planning, communication and warning strategies, and evacuations as part of a response plan. Emergency plans already developed for floods may apply to some extent, but may need modifications for hazards from lahars. For habitats in low-lying areas, a map showing the shortest route to high ground will also be helpful for evacuations.

Knowledge and advance planning are the most important items for dealing with volcano hazards. Especially important is a plan of action based on the knowledge of relatively safe areas around homes, schools, and workplaces. All of the volcano hazards described in this report are serious, and many different hazardous phenomena may affect an area that extends about 7 kilometers from the summit of San Salvador volcano. Lahars pose the biggest threat to people living, working, or recreating along channels that drain San Salvador volcano, even at distances of as much as 
15 kilometers from the volcano. The best strategy for avoiding a lahar is to move to the highest possible ground. A safe height above river channels depends on many factors including the size of the lahar, distance from the volcano, and shape of the valley. For areas beyond about 10 kilometers from the summit of the volcano, all but the largest lahars will rise less than about 20 meters above the channel bottom. San Salvador volcano will erupt again, and the best way to cope with future eruptions is through advance planning in order to mitigate their effects.

\section{REFERENCES}

Bäcklin, C. and Finnson, H., 1994, Landslide hazard at the San Salvador volcano: M.S. thesis, Department of Civil and Environmental Engineering, Royal Institute of Technology, Stockholm, Sweden, $136 \mathrm{p}$.

Baum, R.L., Crone, A.J., Escobar, D., Harp, E.L., Major, J.J., Martinez, M., Pullinger, C.R., and Smith, M.E., 2001, Assessment of landslide hazards resulting from the February 13, 2001, El Salvador earthquake: U.S. Geological Survey Open-File Report 01-119, 22 p.

Hart, W.J.E., and Steen-McIntyre, V., 1983, Tierra Blanca Joven tephra from the A.D. 260 eruption of Ilopango caldera, in Sheets, P.D., ed., Archeaology and Volcanism in Central America: University of Texas Press, Austin, p. 14-34.

Hayashi, J.N., and Self, S., 1992, A comparison of pyroclastic flow and debris avalanche mobility: Journal of Geophysical Research, v. 97, p. 9063-9071.

Iverson, R.M., Schilling, S.P., and Vallance, J.W., 1998, Objective delineation of lahar-hazard zones downstream from volcanoes: Geological Society of America Bulletin, v. 110, p. 972-984.

Major, J.J., Pierson, T.C., Dinehart, R.L., and Costa, J.E., 2000, Sediment yield following severe volcanic disturbance-A two decade perspective from Mount St. Helens: Geology, v. 28, p. 819-822.

Malin, M.C., and Sheridan, M.F., 1982, Computerassisted mapping of pyroclastic surges: Science, v. 217, p. 637-640.

Mercado, R., Rose, W.I., Najera, L., Matías, O., and Girón, J., 1988, Volcanic ashfall hazards and upper wind patterns in Guatemala, preliminary report: Publication of Department of Geological Engineering and Sciences, Michigan Technological University: Houghton, MI, 34 p.

Portig, W.H., 1976, The climate of Central America, in Schwerdtfeger, W., ed., World Survey of Climatology, Climates of Central and South America, v. 12: Elsevier, New York, p. 405-478.

Rose, W.I., Conway, F.M., Pullinger, C.R., Deino, A., and McIntosh, W.C., 1999, An improved age framework for late Quaternary silicic eruptions in northern Central America: Bulletin of Volcanology, v. 61, p. 106-120.

Rymer, M.J., and White, R.A., 1989, Hazards in El Salvador from earthquake-induced landslides, in Brabb, E.E., and Harrod, B.L., eds., Landslides: Extent and Economic Significance. Balkema, Rotterdam, p. 105-109

Sofield, D.J., 1998, History and hazards of Volcan San Salvador, El Salvador: M.S. thesis, Michigan Technological University, 116 p.

\section{ADDITIONAL SUGGESTED READING}

Blong, R.J., 1984, Volcanic hazards: Academic Press, Orlando, FL., 424 p.

Sigurdsson, H., Houghton, B., McNutt, S.R., Rymer, H., and Stix, J., eds., 2000, Encyclopedia of Volcanoes: Academic Press, San Diego, CA., $1417 \mathrm{p}$.

Tilling, R.I., ed., 1989, Volcanic hazards: Short course in geology, v. 1, American Geophysical Union, Washington, D.C., 123 p.

\section{END NOTES}

[1] The geologic data upon which this report is based come largely from Sofield (1998); Bäcklin and Finnson (1994); communications with personnel at Centro de Investigaciones Geotécnicas, San Salvador; and our own reconnaissance investigations.

[2] Diario del Hoy reported on gas emissions, acid rain, and crop damage at coffee plantations around Santa Ana volcano in a story published on January 19, 2001.

[3] Analyses of limited data from volcanoes around the world indicate that sediment yields from river channels filled with volcanic debris by an eruption can remain higher than typical 
background levels for years to decades after an eruption. In some cases sediment yields can remain 10 to 100 times greater than typical background levels for more than two decades (Major et al., 2000). River channels heavily clogged with sediment typically are unstable. Heavy sediment deposition causes a river to wander across the valley floor, which can trigger significant bank erosion that further adds to a river's sediment load.

[4] Ages of eruptions from large silicic calderas in Central America are given in Rose et al. (1999). Detailed discussion of the Tierra Blanca Joven (TBJ) tephra from Ilopango caldera is given in Hart and Steen-McIntyre (1983).

[5] Upper-level wind patterns in Guatemala are given in Mercado et al. (1988). Diurnal and seasonal surface-wind patterns in San Salvador are given in Portig (1976).

[6] The maximum extent of the proximal volcanic hazard zone is estimated from the formula $\mathrm{H} / \mathrm{L}=0.2$, where $\mathrm{H}$ is the elevation difference between the summit rim of El Boquerón and the hazard boundary line, and L is the horizontal distance from the center of the summit crater to the hazard boundary line (see, for example, Malin and Sheridan, 1982; Hayashi and Self, 1992; and Iverson et al., 1998). The value 0.2 was selected because it approximately encompasses the distal extent of lavas erupted from the central summit area, and because it is consistent with $\mathrm{H} / \mathrm{L}$ ratios of proximal hazardous phenomena at many other volcanoes.

[7] Lahar hazard zones were constructed by modeling lahar volumes of 100,000; 300,000; 500,$000 ; 1$ million, and on the east flank of the volcano, 2 million cubic meters. Using mathematical and digital cartographic techniques (Iverson et al., 1998), these volumes were used to compute the estimated extent of inundation down stream from a source area. Historical landslides from San Salvador volcano have had estimated volumes of as much as 300,000 cubic meters (Bäcklin and Finnson, 1994; Centro de Investigaciones Geotécnicas, personal communication); regional earthquake- and rainfall-triggered landslides have estimated volumes of more than 10 million cubic meters, but most landslides triggered by these mechanisms have had volumes of a few hundred to a few tens of thousands of cubic meters (Rymer and White, 1989; Baum et al., 2001; E.L. Harp and A.J. Crone, U.S. Geological Survey, personal communication). At Casita volcano in Nicaragua, extremely heavy rainfall from Hurricane Mitch triggered a landslide of about 1.5 million cubic meters in volume, but as it moved down slope it transformed into a lahar that scoured its channel and its volume enlarged to more than 3 million cubic meters (K.M. Scott, U.S. Geological Survey, personal communication). On the basis of these data, we select a landslide and associated lahar of 1 million cubic meters to be a probable maximum size likely to be triggered in most channels at San Salvador volcano by earthquakes or torrential rainfalls. Locally, we use a larger design lahar as noted below.

A volume of 10 million cubic meters is considered the largest likely debris avalanche from San Salvador volcano, on the basis of the following analogy to the 1980 debris avalanche of Mount St. Helens and other geologic arguments. The 1980 Mount St. Helens avalanche removed about 2300 million cubic meters from the north flank of the volcano, which had an average slope of about 30 degrees. This avalanche removed about $25 \%$ of the cone's total volume above the altitude at which the failure plane intersected the lower north flank. In contrast to Mount St. Helens, San Salvador volcano has a broader topographic profile and, with the exception of El Picacho, few slopes exceed about 20 degrees. On El Picacho, slopes above 1400 meters altitude equal or exceed 30 degrees, and the volume above 1400 meters is about 950 million cubic meters. If the $25 \%$ value from Mount St. Helens is applied to San Salvador, then the maximum volume of a large debris avalanche from El Picacho is slightly more than 200 million cubic meters. The analogy with Mount St. Helens, however, is for a debris avalanche triggered by local magmatic intrusion. El Picacho is significantly separated from the central crater of San 
Salvador, is composed of relatively unaltered lava flows, and is unlikely to produce such a large debris avalanche unless the volcano undergoes extreme deformation. Future magma intrusion is likely to occur in the central vent or along the weak fault zones on the northwest flank of the volcano rather than beneath El Picacho. In our judgement, a better estimate of the largest debris avalanche that could come from El Picacho is perhaps on the order of 10 million cubic meters, similar in volume to a recent earthquake-triggered landslide along the Río Jiboa near San Vicente volcano (Baum et al., 2001). San Salvador volcano does not have a geologic history of producing large landslides, and many of the largest landslides generated throughout the country by strong earthquakes in 2001 were less than 1 million cubic meters (E.L. Harp and A.J. Crone, U.S. Geological Survey, personal communication). Although we limit the largest likely debris avalanche to 10 million cubic meters, we think that a lahar of this volume is not likely to flow down a single channel. The east flank of San Salvador volcano is deeply dissected with closely spaced channels. Thus a large debris avalanche would likely be dispersed among several channels. Accordingly we selected 2 million cubic meters as the largest lahar volume that might travel along any single channel beneath El Picacho.

[8] The annual probability of a lahar having of volume that equals or exceeds 1 million cubic meters from San Salvador volcano is less than 1 in 40,000 . We estimate this probability on the basis of the observation that no deposits from a lahar of this size are found in the geologic record at least since the time of the explosive eruption that emplaced the G1 tephra fall about 40,000 to 50,000 years ago. We estimate possible annual probabilities of landslides and lahars having volumes of about 300,000 cubic meters or less as follows.

Historical earthquake-induced landslides have occurred throughout El Salvador at least a dozen times from 1857 to 2001 (Rymer and White, 1989; Baum et al., 2001). Volumes of these landslides have ranged from a few hundred to more than 10 million cubic meters, but most have had volumes of less than a few to a few tens of thousands of cubic meters. Thus, earthquake-induced landslides of small to moderate volume occur in El Salvador about once every 12 years. At San Salvador volcano, the rainfall that triggered the approximately 300,000 cubic meter landslide in 1982 was the greatest on record at some stations, and nearly equal to the greatest on record at others. The longest precipitation record in the area extends more than 50 years (Bäcklin and Finnson, 1994). Thus the 1982 landslide and lahar perhaps had an annual probability of less than 1 in 50. However, a similarly sized landslide occurred in an adjacent gully sometime in the 1940's (Centro de Investigaciones Geotécnicas, personal communication). At San Vicente volcano, landslides and lahars of comparable volumes have occurred at least four times in the past 225 years, and at least three times in the past 65 years, suggesting that such events there may have an annual probability of occurrence of about 1 in 60 to 1 in 20. Although these probabilities are highly generalized across the region rather than specific to San Salvador volcano, we conclude that the annual probability of landslides and lahars $\leq 300,000$ cubic meters in size at San Salvador volcano is about 1 in 100 to perhaps as great as 1 in 10 . 
